\title{
A Systematic Review of the Mercury Content of the Normal Human Prostate Gland
}

Prof. Dr V. Zaichick

Principal Investigator, Department of Radionuclide Diagnostics, Medical Radiological Research Center, Korolyev St.- 4, Obninsk 249036, Kaluga Region, Russia.

*Corresponding Author: Prof., Dr. V. Zaichick, Medical Radiological Research Centre, Korolyev St. 4, Obninsk 249036, Russia.

Abstract

Background: The prostate gland is subject to various disorders. The etiology and pathogenesis of these diseases remain not well understood. Moreover, despite technological advancements, the differential diagnosis of prostate disorders has become progressively more complex and controversial. It was suggested that the mercury $(\mathrm{Hg})$ level in prostatic tissue plays an important role in prostatic carcinogenesis and its measurement may be useful as a cancer biomarker. These suggestions promoted more detailed studies of the $\mathrm{Hg}$ content in the prostatic tissue of healthy subjects.

Materials and Methods: The present study evaluated by systematic analysis the published data for $\mathrm{Hg}$ content analyzed in prostatic tissue of "normal" glands. This evaluation reviewed 1978 studies, all of which were published in the years from 1921 to 2020 and were located by searching the databases Scopus, PubMed, MEDLINE, ELSEVIER-EMBASE, Cochrane Library, and the Web of Science. The articles were analyzed and "Median of Means" and "Range of Means" were used to examine heterogeneity of the measured Hg content in prostates of apparently healthy men..

Results: The objective analysis was performed on data from the 22 studies, which included 1194 subjects. It was found that the range of means of prostatic $\mathrm{Hg}$ content reported in the literature for "normal" gland varies widely from $0.0043 \mathrm{mg} / \mathrm{kg}$ to $0.11 \mathrm{mg} / \mathrm{kg}$ with median of means $0.0075 \mathrm{mg} / \mathrm{kg}$ on a wet mass basis and the level of intra-prostatic metal increases with age in adults.

Conclusion: Because of small sample size and high data heterogeneity, we recommend other primary studies be performed.

Keywords: Mercury; Human prostate; Normal prostatic tissue; Trace elements: Biomarkers.

\section{INTRODUCTION}

The prostate gland is subject to various disorders and of them chronic prostatitis, benign prostatic hyperplasia (BPH), and prostate cancer ( $\mathrm{PCa}$ ) are extremely common diseases of ageing men [1-3]. The etiology and pathogenesis of these diseases remain not well understood. A better understanding of the etiology and causative risk factors are essential for the primary prevention of these diseases.

In our previous studies the significant involvement of trace elements (TEs) in the function of the prostate was found. [4-15]. It was also shown that levels of TEs in prostatic tissue, including mercury $(\mathrm{Hg})$, can play a significant role in etiology of PCa [16-20]. Moreover, it was demonstrated that the changes of some TE levels and $\mathrm{Zn} / \mathrm{Hg}$ ratios in prostate tissue can be used as biomarkers [21-27].

Hg has a reputation for being a dangerous element and in past time many people who worked with mercury, for example, miners, mirror makers, hatters, dentists, medical doctors, scientist, and so on, had a lot of problems with their health. Although elemental Hg was clearly toxic, this did not stop its use in pharmacy for hundreds of years. So, the investigations on $\mathrm{Hg}$ toxicity have a long story but an intensive study of 
problem started after an epidemic in Minamata City in Kumamoto prefecture, Japan in 1956 in which a large number of people died [28].

Among papers reviewed in present study the first result of $\mathrm{Hg}$ content in human prostate was published in 1967 [29]. It was indicated that mean level of $\mathrm{Hg}$ in human prostates of five adults was $0.11 \mathrm{mg} / \mathrm{kg}$ of wet tissue [29]. This finding allowed made the inference that the prostate gland accumulates $\mathrm{Hg}$, because the level of metal in prostate was two orders of magnitude higher the blood serum reference concentration (0.001 mg/L) [30]. Metallic $\mathrm{Hg}$ and inorganic compounds of this metal are classified as Group 3 (i.e. 'not classifiable as carcinogenic to humans') by the International Agency for Research on Cancer [31] However, a few epidemiological studies have reported increased cancer incidence (central nervous system, lung, liver, renal and gastric cancer) or mortality associated with occupations involving potential exposure to elemental Hg vapour among workers in chloralkali plants and the nuclear weapon industry, as well as dental professionals [32-37]. Moreover, it was found that higher blood $\mathrm{Hg}$ level were associated with a higher prevalence of prostate malignant tumors and nonmelanoma skin cancer [38,39]. These findings promoted more detailed studies of the Hg content of prostatic tissue of healthy subjects, as well as of patients with different prostatic diseases, including $\mathrm{BPH}$ and PCa.

The effects of TEs, including Hg, are related to their concentration. Recorded observations range from a deficiencystate,throughnormalfunctionasbiologically essential components, to an imbalance, when excess of one element interferes with the function of another, to pharmacologically active concentrations, and finally to toxic and even life-threatening concentrations [40-42]. In this context, significant Hg exposure may result in adverse health effects in different organs or tissues, including malignancy [32-39,43]. However, precise molecular mechanisms by which this metal causes healthy cells to transform to malignant states are not well understood, but there are some plausible hypotheses: oxidative stress and disruption of DNA repair [39].

By now, a few studies have reported the Hg content in tissue of "normal" and affected glands. However, further investigation has been considered necessary to provide a practical reference data of $\mathrm{Hg}$ levels in prostate norm and disorders, because the findings of various studies indicate some discrepancies.

The present study addresses the significance of $\mathrm{Hg}$ levels in prostatic tissue as a biomarker of the gland's condition. Therefore, we systematically reviewed all the available relevant literature and performed a statistical analysis of $\mathrm{Hg}$ content in tissue of "normal" glands, which may provide valuable insight into the etiology and diagnosis of prostate disorders.

\section{MATERIALS AND METHODS}

\section{Data Sources and Search Strategy}

Aiming at finding the most relevant articles for this review, a thorough comprehensive web search was conducted by consulting the Scopus, PubMed, MEDLINE, ELSEVIER-EMBASE, Cochrane Library, and the Web of Science databases, as well as from the personal archive of the author collected between 1966 to August 2020, using the key words: prostatic trace elements, prostatic $\mathrm{Hg}$ content, prostatic tissue, and their combinations. For example, the search terms for Hg content were: "Hg mass fraction", "Hg content", "Hg level", "prostatic tissue Hg" and "Hg of prostatic tissue". The language of the article was not restricted. The titles from the search results were evaluated closely and determined to be acceptable for potential inclusion criteria. Also, references from the selected articles were examined as further search tools. Relevant studies noted for the each selected article were also evaluated for inclusion.

\section{Eligibility Criteria}

Inclusion criteria: Only papers with quantitative data of $\mathrm{Hg}$ prostatic content were accepted for further evaluation. Studies were included if the control groups were healthy human males with no history or evidence of urological or other andrological disease and $\mathrm{Hg}$ levels were measured in samples of prostatic tissue.

Exclusion criteria: Studies were excluded if they were case reports. Studies involving subjects that were $\mathrm{Hg}$ occupational exposed, as well as persons from $\mathrm{Hg}$ contaminated area were also excluded.

\section{Data Extraction}

A standard extraction of data was applied, and the 
following available variables were extracted from each paper: method of $\mathrm{Hg}$ determination, number and ages of healthy persons, sample preparation, mean and median of Hg levels, standard deviations of mean, and range of $\mathrm{Hg}$ levels. Abstracts and complete articles were reviewed independently, and if the results were different, the texts were checked once again until the differences were resolved.

\section{Statistical Analysis}

Studies were combined based on means of Hg levels in prostatic tissue. The articles were analyzed and "Median of Means" and "Range of Means" were used to examine heterogeneity of $\mathrm{Hg}$ contents. The objective analysis was performed on data from the 22 studies, with 1194 subjects.

\section{RESULTS}

Information about $\mathrm{Hg}$ levels in prostatic tissue in different prostatic diseases is of obvious interest, not only to understand the etiology and pathogenesis of prostatic diseases more profoundly, but also for their diagnosis, particularly for PCa diagnosis and PCa risk prognosis $[27,38]$. Thus, it dictates a need for reliable values of the $\mathrm{Hg}$ levels in the prostatic tissue of apparently healthy subjects, ranging from young adult males to elderly persons.

Possible publications relevant to the keywords were retrieved and screened. A total of 1978 publications were primarily obtained, of which 1956 irrelevant papers were excluded. Thus, 22 studies were ultimately selected according to eligibility criteria that investigated $\mathrm{Hg}$ levels in tissue of normal prostates (Table 1) and these 22 papers $[7,9,11,13,14,24,26,29,44-57]$ comprised the material on which the review was based. A number of values for $\mathrm{Hg}$ mass fractions were not expressed on a wet mass basis by the authors of the cited references. However, we calculated these values using the medians of published data for water - 83\% [58-61] and ash - 1\% (on a wet mass basis) contents in normal prostates of adult men [60,62-64].

Table 1 summarizes general data from the 22 studies. The retrieved studies involved 1194 subjects. The ages of subjects were available for 20 studies and ranged from 0-87 years. Information about the analytical method and sample preparation used was available for 22 studies. Three studies determined $\mathrm{Hg}$ levels by destructive (require high temperature drying and acid digestion) analytical methods (Table 1): one - inductively coupled plasma mass spectrometry (ICPMS) and two - radiochemical neutron activation analysis (RNAA). Seven studies detected $\mathrm{Hg}$ level in intact prostatic tissue samples by nondestructive analytical method, such as instrumental neutron activation analysis (INAA). In twelve studies a combination of destructive and nondestructive methods (ICPMS and INAA) was used and results were summarized.

Figure 1 illustrates the data set of $\mathrm{Hg}$ measurements in 22 studies during the period from 1956 to 2020 ..

\section{Discussion}

The range of means of $\mathrm{Hg}$ mass fractions reported in the literature for "normal" prostatic tissue varies widely from $0.0043 \mathrm{mg} / \mathrm{kg}$ [7] to $0.11 \mathrm{mg} / \mathrm{kg}$ [29] with median of means $0.0075 \mathrm{mg} / \mathrm{kg}$ of wet tissue and Mmax/Mmin ratio approximately 26 (Table 1). This variability of reported mean values can be explained a priori by a dependence of Hg content on many factors, including analytical method imperfections, differences in "normal" prostate definitions, possible nonhomogeneous distribution of $\mathrm{Hg}$ levels throughout the prostate gland volume, age, ethnicity, diet, smoking, alcohol intake, consuming supplemental trace elements, and others. Not all these factors were strictly controlled in the cited studies. For example, in some studies the "normal" prostate means a gland of an apparently healthy man who had died suddenly, but without any morphological confirmation of "normality" of his prostatic tissue. In other studies the "normal" prostate means a non-cancerous prostate (but hyperplastic and inflamed glands were included) and even a visually normal prostatic tissue adjacent to a prostatic malignant tumor. Some researchers used as the "normal" prostate the glands of patients who died from acute and chronic non-prostatic diseases including subjects who had suffered from prolonged wasting illnesses. In some studies whole glands were used for the investigation while in others the $\mathrm{Hg}$ content was measured in pieces of the prostate. Therefore published data allowed us to estimate the effect of only some factors on Hg content in "normal" prostate tissue. 
A Systematic Review of the Mercury Content of the Normal Human Prostate Gland

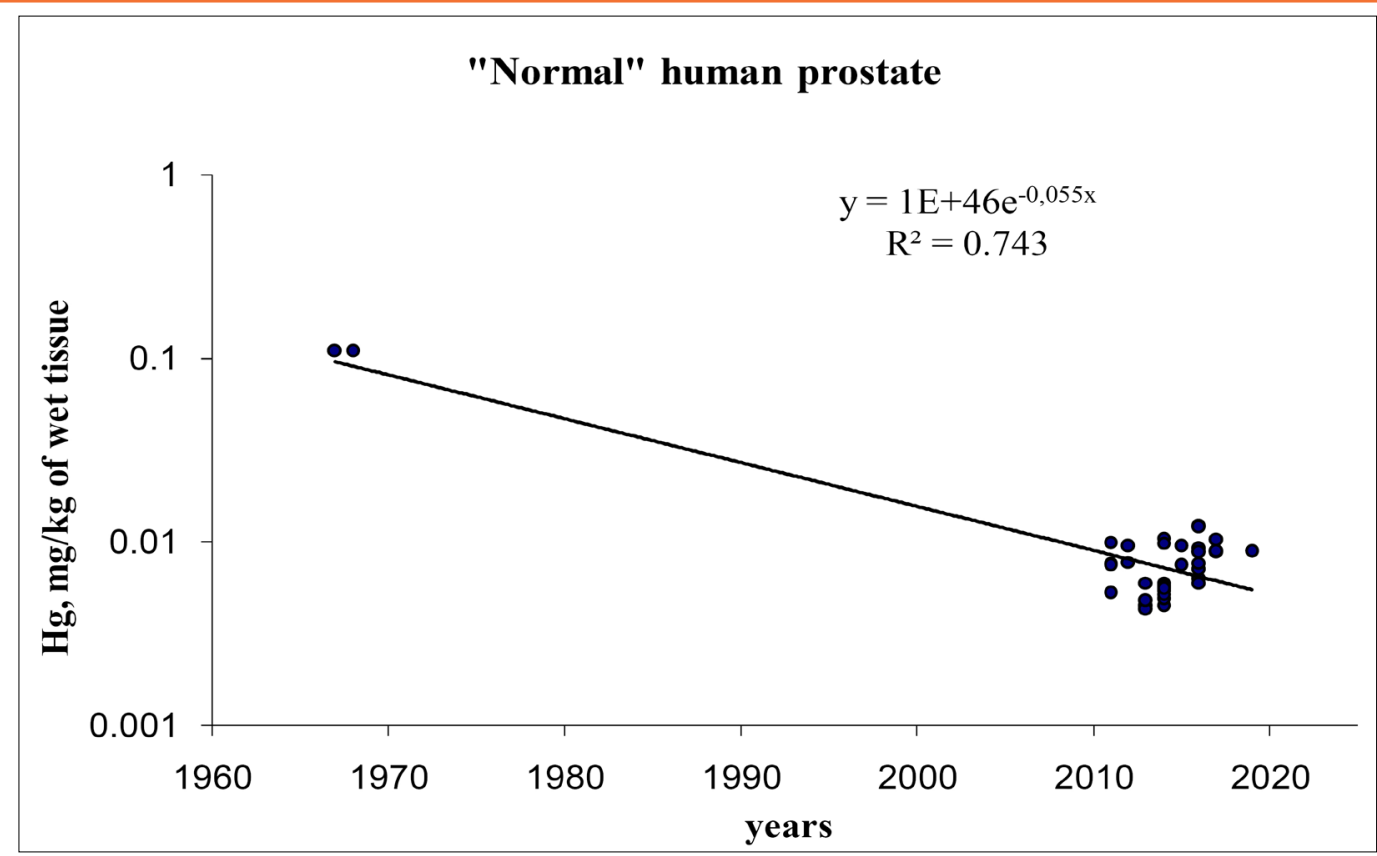

Figure1. Data on Hg content in normal prostate tissue reported from 1967 to 2020.

\section{Analytical Method}

The trend line of $\mathrm{Hg}$ content data in "normal" prostate (Figure 1) showed that an improvement of analytical technologies during last 50 years impacted significantly on the mean of reported values. In our opinion, the leading cause of differences between results published in 1960s and 2010s is a lack of quality control of results with using Certified Reference Materials (CRMs) in old studies.

In some reported papers such destructive analytical methods as RNAA and ICP-MS were used. These methods require acid digestion of the samples at a high temperature. There is evidence that use of this treatment causes some quantities of TEs to be lost $[40,65,66]$. On the other hand, the $\mathrm{Hg}$ content of chemicals used for acid digestion can contaminate the prostate samples. Thus, when using destructive analytical methods it is necessary to allow for the losses of TEs, for example when there is complete acid digestion of the sample. Then there are contaminations by TEs during sample decomposition, which require addition of some chemicals.

Table1. Reference data of Hg mass fractions ( $\mathrm{mg} / \mathrm{kg}$ wet tissue) in "normal" human prostatic tissue

\begin{tabular}{|c|c|c|c|c|c|c|}
\hline \multirow[t]{2}{*}{ Reference } & \multirow[t]{2}{*}{ Method } & \multirow[t]{2}{*}{$\mathrm{n}$} & \multirow{2}{*}{$\begin{array}{c}\text { Age range } \\
\text { years }\end{array}$} & \multirow{2}{*}{$\begin{array}{c}\text { Sample } \\
\text { preparation }\end{array}$} & \multicolumn{2}{|c|}{$\mathrm{Hg}$} \\
\hline & & & & & $\mathrm{M} \pm \mathrm{SD}$ & Range \\
\hline Smith 1967 [29] & RNAA & 5 & Adult & $\mathrm{D}, \mathrm{AD}$ & 0.11 & $0.0068-0.26$ \\
\hline Liebscher et al., 1968 [44] & RNAA & 5 & Adult & $\mathrm{D}, \mathrm{AD}$ & $0.11 \pm 0.10$ & $0.0068-0.26$ \\
\hline \multirow[t]{4}{*}{ Zaichick et al., 2011 [45] } & INAA & 64 & $13-60$ & Intact & $0.0077 \pm 0.0078$ & $0.001-0.041$ \\
\hline & & 9 & $13-20$ & Intact & $0.0075 \pm 0.0097$ & - \\
\hline & & 28 & $21-40$ & Intact & $0.0053 \pm 0.0034$ & - \\
\hline & & 27 & $41-60$ & Intact & $0.010 \pm 0.011$ & - \\
\hline Zaichick et al., 2012 [24] & INAA & 37 & $66 \pm 8$ & Intact & $0.0095 \pm 0.0097$ & $0.0013-0.041$ \\
\hline Zaichick et al., 2012 [46] & ICPMS & 64 & $13-60$ & $\mathrm{AD}$ & $0.0078 \pm 0.0075$ & 0.0011-0.045 \\
\hline \multirow[t]{2}{*}{ Zaichick et al., 2013 [7] } & INAA & 29 & $0-13$ & Intact & $0.0045 \pm 0.0032$ & - \\
\hline & & 21 & $14-30$ & Intact & $0.0043 \pm 0.0022$ & - \\
\hline Zaichick et al., 2013 [9] & 2 Methods & 29 & $0-13$ & Intact, $\mathrm{AD}$ & $0.0060 \pm 0.0061$ & - \\
\hline
\end{tabular}


A Systematic Review of the Mercury Content of the Normal Human Prostate Gland

\begin{tabular}{|c|c|c|c|c|c|c|}
\hline & & 21 & $14-30$ & Intact, $\mathrm{AD}$ & $0.0048 \pm 0.0024$ & - \\
\hline \multirow[t]{3}{*}{ Zaichick et al., 2014 [47] } & INAA & 28 & $21-40$ & Intact & $0.0054 \pm 0.0034$ & $0.0014-0.0170$ \\
\hline & & 27 & $41-60$ & Intact & $0.0104 \pm 0.0102$ & 0.0013-0.041 \\
\hline & & 10 & $61-87$ & Intact & $0.0045 \pm 0.0015$ & 0.0036-0.0067 \\
\hline \multirow[t]{3}{*}{ Zaichick et al., 2014 [48] } & 2 Methods & 28 & $21-40$ & Intact, $\mathrm{AD}$ & $0.0060 \pm 0.0037$ & $0.0022-0.0170$ \\
\hline & & 27 & $41-60$ & Intact, $\mathrm{AD}$ & $0.0099 \pm 0.0075$ & $0.0013-0.0250$ \\
\hline & & 10 & $61-87$ & Intact, $\mathrm{AD}$ & $0.0063 \pm 0.0061$ & $0.0034-0.0221$ \\
\hline \multirow[t]{3}{*}{ Zaichick et al., 2014 [11] } & INAA & 29 & $0-13$ & Intact & $0.0056 \pm 0.0040$ & \\
\hline & & 21 & $14-30$ & Intact & $0.0049 \pm 0.0024$ & \\
\hline & & 50 & $0-30$ & Intact & $0.0052 \pm 0.0033$ & \\
\hline Zaichick et al., 2014 [13] & 2 Methods & 16 & $20-30$ & Intact, $\mathrm{AD}$ & $0.0049 \pm 0.0024$ & - \\
\hline \multirow[t]{3}{*}{ Zaichick et al., 2014 [14] } & 2 Methods & 50 & $0-30$ & Intact, $\mathrm{AD}$ & $0.0057 \pm 0.0033$ & \\
\hline & & 29 & $0-13$ & Intact, $\mathrm{AD}$ & $0.0058 \pm 0.0041$ & \\
\hline & & 21 & $14-30$ & Intact, $\mathrm{AD}$ & $0.0056 \pm 0.0025$ & \\
\hline Zaichick et al., 2015 [49] & INAA & 32 & $44-87$ & Intact & $0.0095 \pm 0.0102$ & 0.0013-0.041 \\
\hline Zaichick 2015 [50] & 2 Methods & 65 & $21-87$ & Intact, $\mathrm{AD}$ & $0.0075 \pm 0.0061$ & - \\
\hline \multirow[t]{3}{*}{ Zaichick et al., 2016 [51] } & INAA & 28 & $21-40$ & Intact & $0.0063 \pm 0.0043$ & $0.0019-0.0214$ \\
\hline & & 27 & $41-60$ & Intact & $0.0122 \pm 0.0114$ & $0.0014-0.0480$ \\
\hline & & 10 & $61=87$ & Intact & $0.0060 \pm 0.0019$ & $0.0045-0.0086$ \\
\hline \multirow[t]{4}{*}{ Zaichick et al., 2016 [52] } & 2 Methods & 65 & $21-87$ & Intact, $\mathrm{AD}$ & $0.0092 \pm 0.0074$ & $0.0015-0.0352$ \\
\hline & & 28 & $21-40$ & Intact, $\mathrm{AD}$ & $0.0071 \pm 0.0009$ & - \\
\hline & & 27 & $41-60$ & Intact, $\mathrm{AD}$ & $0.0121 \pm 0.0020$ & - \\
\hline & & 10 & $61=87$ & Intact, $\mathrm{AD}$ & $0.0077 \pm 0.0023$ & - \\
\hline Zaichick et al., 2016 [53] & 2 Methods & 32 & $44-87$ & Intact, $\mathrm{AD}$ & $0.0088 \pm 0.0077$ & - \\
\hline Zaichick et al., 2016 [54] & 2 Methods & 37 & $41-87$ & Intact, $\mathrm{AD}$ & $0.0088 \pm 0.0082$ & - \\
\hline Zaichick et al., 2017 [26] & 2 Methods & 37 & $41-87$ & Intact, $\mathrm{AD}$ & $0.0088 \pm 0.0082$ & - \\
\hline Zaichick et al., 2017 [55] & 2 Methods & 37 & $41-87$ & Intact, $\mathrm{AD}$ & $0.0103 \pm 0.0084$ & 0/0014-0.0335 \\
\hline Zaichick, 2017 [56] & 2 Methods & 37 & $41-87$ & Intact, $\mathrm{AD}$ & $0.0089 \pm 0.0072$ & $0.0013-0.0250$ \\
\hline Zaichick et al., 2019 [57] & 2 Methods & 37 & $41-87$ & Intact, $\mathrm{AD}$ & $0.0089 \pm 0.0072$ & $0.0013-0.0250$ \\
\hline \multicolumn{2}{|c|}{ Median of means } & \multicolumn{5}{|c|}{0.0075} \\
\hline \multicolumn{2}{|c|}{ Range of means $\left(\mathrm{M}_{\min }-\mathrm{M}_{\max }\right)$, } & \multicolumn{5}{|c|}{$0.0043-0.11$} \\
\hline \multicolumn{2}{|c|}{ Ratio $\mathrm{M}_{\max } / \mathrm{M}_{\min }$} & \multicolumn{5}{|c|}{25.6} \\
\hline \multicolumn{2}{|c|}{ All references } & \multicolumn{5}{|c|}{22} \\
\hline
\end{tabular}

$\mathrm{M}$ - arithmetic mean, SD - standard deviation of mean,

RNAA - radiochemical neutron activation analysis, NAA - instrumental neutron activation analysis, ICPMS inductively coupled plasma mass spectrometry; 2 Methods -NAA and ICPMS, D - drying at high temperature, $\mathrm{AD}$ - acid digestion.

It is possible to avoid these problems by using nondestructive methods, such as INAA, which allow quantify $\mathrm{Hg}$ content in "normal" prostate without acid digestion. Moreover, a good agreement between results obtained by both INAA and ICPMS methods under a strong quality control with using CRMs

[9,13,14,26,52-54,55-57] shoved that in case of $\mathrm{Hg}$ it is possible to avoid uncertainties connected with acid digestion. It is, therefore, reasonable to conclude that the quality control of results is very important factor for using the Hg content in prostatic tissue as biomarkers. 


\section{Age}

In a few studies a significant increase in $\mathrm{Hg}$ content with increasing of age of adults was shown by the comparison of different age groups or the Pearson's coefficient of correlation between age and Hg content in prostate tissue $[47,48,50-52]$. For example, a strongly pronounced tendency for an age-related increase of Hg mass fraction was observed in the prostate for the third to six decades [50]. In prostates of 50 year old men, the mean $\mathrm{Hg}$ mass fraction was 2-3 times greater than that in the prostates of 20 year old males [50]. Thus, the accumulated information, studied by us from reported data, allowed a conclusion that there is a significant increase in Hg mass fraction in "normal" prostate from age 21 years to the six decade.

\section{Androgen-Independence of Prostatic $\mathrm{Hg}$ levels}

There was not found any difference between $\mathrm{Hg}$ levels in prostates of teenagers before puberty and of postpubertal teenagers and young adults $[7,9,11,13,14]$. These findings allowed us to conclude that the Hg content in "normal" prostates does not depend on the level of androgens, and vice versa. However, studies on the association between the Hg content in "normal" prostates and the level of androgens in blood were not found.

\section{Hg Intake}

In the general population, potential sources of $\mathrm{Hg}$ exposure include the inhalation of this metal vapor in the air, ingestion of contaminated foods and drinking water, and exposure to dental amalgam through dental care [67]. Fish, shellfish and marine products consumption is one of the major route of human exposure to Hg [43]. Recent studies indicate that rice consumption could also contribute significantly to human exposure to $\mathrm{Hg}$, but especially in Asia [68]. A strong positive association between alcohol consumption and blood $\mathrm{Hg}$ levels was also reported [67]. The Joint Food and Agriculture Organization of the United Nations and World Health Organization FAO/WHO Expert Committee on Food Additives (JECFA) has established provisional tolerable weekly intake (PTWI) for total Hg, The PTWI for Hg of 4.0 $\mu \mathrm{g} / \mathrm{kg}$ body weight/week corresponds to $0.280 \mathrm{mg} /$ week for a person weighing $70 \mathrm{~kg}$ [69]. Other general population exposures may result from dental fillings (dental amalgam is made up of approximately 40$50 \% \mathrm{Hg}, 25 \% \mathrm{Ag}$, and $25-35 \%$ blend of $\mathrm{Cu}, \mathrm{Zn}$ and $\mathrm{Sn}$ ) and using or breaking products containing $\mathrm{Hg}$ such as some thermometers, barometers, novelty jewelry and etc $[37,69]$.

\section{Hg Content in Body Fluids, Tissues and Organs}

It is known that $\mathrm{Hg}$ is deposited primarily in the brain, lung, liver, kidney, adrenals, pancreas, muscles including myocardium, thyroid, breast, prostate, testes, enterocytes, skin, sweat and salivary glands [69]. Mass fraction of this metal in blood serum of the Reference Man is lower $0.001 \mathrm{mg} / \mathrm{L}$ [30]. The median of prostatic Hg content means obtained in the present review $(0.0075 \mathrm{mg} / \mathrm{kgof}$ wet tissue) is almost one order of magnitude higher the blood serum value. Thus, we can confirm that the prostate is a target organ for Hg. An increase of Hg intake associated with an increase of metal concentration in blood $[67,70]$, and, as a consequence in different organs, including the prostate.

All natural chemical elements of the Periodic System, including $\mathrm{Hg}$, present in all subjects of biosphere $[41,71,72]$. During the long evolutional period intakes of $\mathrm{Hg}$ were more or less stable and organisms were adopted for such environmental conditions. People use metallic $\mathrm{Hg}$ in very small amounts for a long time. Mercury has been found in Egyptian tombs dating to about 1500 B.C., and it was probably used for cosmetic and medicinal purposes even earlier.

The situation very changed after the industrial revolution, particularly, after 1900 when $\mathrm{Hg}$ found its way into many products and industrial applications. Principal applications of $\mathrm{Hg}$ are in the production of chlorine and caustic soda. Other uses for metallic Hg and Hg compounds include production of light bulbs, light switches, electrical equipment, batteries, semiconductors, instrument engineering (barometers and thermometers), explosives, jewelries, paints, sporting equipment, fungicides, and pesticides. Hg is also used as part of the processes to produce car, paper, felt, leather, glass, and many plastics, as well as as a preservative or antibacterial agent in medical and pharmaceutical applications (antibiotics, blood pressure cuffs, contact 
lens solution, dental amalgam, diuretics, ear and eye drops, eye ointment, hemorrhoid relief ointment, nasal spray, and medical thermometers).

Environmental Hg pollution occurs mainly through a combination of land (through atmospheric emissions originating from mining and refining, various manufacturing operations, residues from coal, oil, and gas combustion, urban refuse, and also from waste, fungicides, pesticides, and sewage sludge application), water (through irrigation, industrial liquid waste, and sewage sludge), and air (through atmospheric industrial emissions and vehicle exhaust) contamination and is subsequently introduced into the food chain. Worldwide, in 1988 approximately 11 $\mathrm{t}$ of $\mathrm{Hg}$ were released into the air, land, and water as the result of human activities. In 2000s global direct emissions to the atmosphere amounted to $30 \mathrm{t}$ per year and the total quantity of $\mathrm{Hg}$ released into the air during the past five centuries exceeded 10000 $\mathrm{t}$ [73]. Thus, the global demand for $\mathrm{Hg}$ and global environmental contamination by this metal increased till now. Moreover, it is likely that this tendency will continue. Age-dependent increase of $\mathrm{Hg}$ mass fractions in the "normal" prostate tissue indirectly confirm this conclusion. If an increase of $\mathrm{Hg}$ in prostate of healthy men living in a non-industrial, ecologically safe region will be confirmed, this could be interpreted as the result of a global increase of the concentrations of $\mathrm{Hg}$ in the environment.

Thus, according our study for not polluted areas no one influencing factor could explain the variability of published means for prostatic $\mathrm{Hg}$ levels from 0.0043 $\mathrm{mg} / \mathrm{kg}$ to $0.11 \mathrm{mg} / \mathrm{kg}$ of wet tissue. Moreover, prostate tissue $\mathrm{Hg}$ contents showed large variations among individuals, but sources of the variation remain unknown. For example, the most powerful factor was age when it was found that the prostatic Hg level of young adults was only 2-3 times lower than that of men aged 50-60 years. It is, therefore, reasonable to assume from data of our study that inaccuracy of analytical technologies employed caused so great variability of published means for prostatic Hg levels. This conclusion was supported the fact that the Certified Reference Materials for quality control of results were not used in studies reported in 1960s $[29,44]$.
There are some limitations in our study, which need to be taken into consideration when interpreting the results of this review. The sample size of each study was sometimes relatively small (from 1 to 65), and a total of 1194 "normal" controls were investigated from all 22 studies. As such, it is hard to draw definite conclusions about the reference value of the Hg content in "normal" prostate as well as about the clinical value of the Hg levels in "normal" prostates as a biomarker.

\section{Conclusion}

The present study is a comprehensive study regarding the determination of $\mathrm{Hg}$ content in "normal" human prostates. With this knowledge Hg levels may then be considered as a biomarker for the recognition of prostate disorders. The study has demonstrated that level of $\mathrm{Hg}$ in "normal" prostates depends on some factors such as age and analytical method. Because of the uncertainties we have outlined, we recommend other primary studies be performed.

\section{REFERENCES}

[1] Nickel JC. Prostatitis. Can UrolAssoc J 2011;5:30615.

[2] Lim KB. Epidemiology of clinical benign prostatic hyperplasia. Asian J Urol 2017;4:148-51.

[3] Rawla P. Epidemiology of Prostate Cancer.World J Oncol 2019;10(2):63-89.

[4] Avisyn AP, Dunchik VN, Zhavoronkov AA, Zaichick VE, Sviridova TV. Histological structure of the prostate and content of zinc in it during various age period. Archiv Anatomy, Gistology, and Ebriology (Leningrad) 1981;81(11):76-83.

[5] Zaichick V. INAA and EDXRF applications in the age dynamics assessment of Zncontent and distribution in the normal human prostate. J RadioanalNucl Chem 2004;262:229-34.

[6] Zaichick V, Zaichick S. The effect of age on $\mathrm{Br}$, Ca, $\mathrm{Cl}, \mathrm{K}, \mathrm{Mg}, \mathrm{Mn}$, and $\mathrm{Na}$ mass fraction in pediatric and young adult prostate glands investigated by neutron activation analysis. ApplRadiatIsot 2013;82:145-51.

[7] Zaichick V, Zaichick S. INAA application in the assessment of $\mathrm{Ag}, \mathrm{Co}, \mathrm{Cr}, \mathrm{Fe}, \mathrm{Hg}, \mathrm{Rb}, \mathrm{Sb}, \mathrm{Sc}, \mathrm{Se}$, 
A Systematic Review of the Mercury Content of the Normal Human Prostate Gland

and $\mathrm{Zn}$ mass fraction in pediatric and young adult prostate glands. J RadioanalNucl Chem 2013;298:1559-66.

[8] Zaichick V, Zaichick S. NAA-SLR and ICP-AES application in the assessment of mass fraction of 19 chemical elements in pediatric and young adult prostate glands. Biol Trace Elem Res 2013;156:357-66.

[9] Zaichick V, Zaichick S. Use of neutron activation analysis and inductively coupled plasma mass spectrometry for the determination of trace elements in pediatric and young adult prostate. Am J Analyt Chem2013;4:696-706.

[10] Zaichick V, Zaichick S. Relations of bromine, iron, rubidium, strontium, and zinc content to morphometric parameters in pediatric and nonhyperplastic young adult prostate glands. Biol Trace Elem Res 2014;157:195-204.

[11] Zaichick V, Zaichick S. Relations of the neutron activation analysis data to morphometric parameters in pediatric and nonhyperplastic young adult prostate glands. Advances in Biomedical Science and Engineering 2014;1:2642.

[12] Zaichick V, Zaichick S. Relations of the $\mathrm{Al}, \mathrm{B}, \mathrm{Ba}$, $\mathrm{Br}, \mathrm{Ca}, \mathrm{Cl}, \mathrm{Cu}, \mathrm{Fe}, \mathrm{K}, \mathrm{Li}, \mathrm{Mg}, \mathrm{Mn}, \mathrm{Na}, \mathrm{P}, \mathrm{S}, \mathrm{Si}, \mathrm{Sr}$, and $\mathrm{Zn}$ mass fractions to morphometric parameters in pediatric and nonhyperplastic young adult prostate glands. BioMetals2014;27:333-48.

[13] Zaichick V, Zaichick S. Androgen-dependent chemical elements of prostate gland. AndrolGynecol: Curr Res 2014;2:2.

[14] Zaichick V, Zaichick S. The distribution of 54 trace elements including zinc in pediatric and nonhyperplastic young adult prostate gland tissues. Journal of Clinical and Laboratory Investigation Updates 2014;2(1):1-15.

[15] ZaichickV, Zaichick S. Differences and relationships between morphometric parameters and zinc content innonhyperplastic and hyperplastic prostate glands.Br J Med Med Res 2015;8:692706.

[16] Schwartz MK. Role of trace elements in cancer. Cancer Res 1975;35:3481-87.
[17] Zaichick V., Zaichick S. Role of zinc in prostate cancerogenesis. In: Mengen und Spurenelemente. 19. Arbeitstagung. Friedrich-Schiller-Universitat, Jena, 1999, pp 104-115.

[18] Zaichick V., Zaichick S. Wynchank S. Intracellular zinc excess as one of the main factors in the etiology of prostate cancer. J Anal Oncol 2016;5:124-31.

[19] Zaichick V, Zaichick S, Rossmann M. Intracellular calcium excess as one of the main factors in the etiology of prostate cancer. AIMS MolSci 2016;3:635-47.

[20] Krstev S, Knutsson A. Occupational risk factors for prostate cancer: A meta-analysis. JCancerPrevAction 2019;24(2):91-111.

[21] Dunchik V, Zherbin E, Zaichick V, Leonov A, Sviridova T. Method for differential diagnostics of prostate malignant and benign tumours. Russian patent (Author's Certificate No 764660, priority of invention 27.10.1977). Discoveries, Inventions, Commercial Models, Trade Marks 1980;35:13.

[22] Zaichick V, Sviridova T, Zaichick S. Zinc in the human prostate gland: normal, hyperplastic and cancerous. IntUrolNephrol 1997;29:565-74.

[23] Zaichick V, Sviridova T, Zaichick S. Zinc in human prostate gland: normal, hyperplastic and cancerous. J RadioanalNucl Chem 1997;217:15761.

[24] Zaichick S, Zaichick V. Trace elements of normal, benign hypertrophic and cancerous tissues of the human prostate gland investigated by neutron activation analysis. J ApplRadiatIsot 2012;70:81-7.

[25] Zaichick V, Zaichick S. Ratios of selected chemical element contents in prostatic tissue as markers of malignancy. Hematol Med Oncol 2016;1(2):1-8.

[26] Zaichick V, Zaichick S. Trace element levels in prostate gland as carcinoma's markers. J Cancer Ther 2017;8:131-45.

[27] Zaichick V, Zaichick S. Ratios of Zn/trace element contents in prostate gland as carcinoma's markers. Cancer Rep Rev 2017;1(1):1-7. 
[28] Toshihide T, Takashi Y. The history of Minamata disease and public health policy. Epidemiology 2011;22(1):S99.

[29] Smith H. The distribution of antimony, arsenic, copper, and zinc in human tissue. J Forensic Science Sos 1967;7:97-102.

[30] Iyengar GV. Reevaluation of the trace element content in reference men. Radiat Phys Chem1998;51:545-60.

[31] International Agency for Research on Cancer. Agents classified by the IARC monographs, volumes 1-127. Available at: https:// monographs.iarc.fr/agents-classified-by-theiarc/ (last accessed 27 October 2020)

[32] Cragle DL, Hollis DR, Qualters JR, Tankersley WJ,Fry SA. A mortality study of men exposed to elemental mercury. J Occup Med1984;26:817821.

[33] Ahlbom A, Norell S, Rodvall Y, Nylander M. Dentists, dental nurses, and brain tumours. BMJ1986;292:662.

[34] Barregård L, Sällsten G, Järvholm B. Mortality and cancer incidence in chloralkali workers exposed to inorganic mercury. Occup Environ Med1990;47:99-104.

[35] Boffetta P, Merler E, Vainio H. Carcinogenicity of mercury and mercury compounds. Scand J Work Environ Health. 1993;19(1):1-7.

[36] Ellingsen DG, Andersen A, Nordhagen HP,Efskind J, Kjuus H. Incidence of cancer and mortality among workers exposed to mercury vapour in the Norwegian chloralkali industry. Occup Environ Med1993;50:875-80.

[37] Carver A, Gallicchio VS. Heavy Metals and Cancer. In: Cancer Causing Substances. FaikAtroshi (ed). IntechOpen, 2017.

[38] Lovakovic BT, Semren TZ, Gamulin T, Pizent A. Trace element concentration in men with newly diagnosed prostate cancer. In: Abstracts of the 5th Croatian Congress of Toxicology with International Participation (CROTOX 2016). Arh Hig Rada Toksikol 2016;67(Suppl. 1):47-53.
[39] Rhee J, Vance TM, Lim R, Christiani DC, Qureshi AA, Cho E. Association of blood mercury levels with nonmelanoma skin cancer in the U.S.A. using National Health and Nutrition Examination Survey data (2003-2016). Br J Dermatol 2020;183(3):480-7.

[40] Zaichick V. Medical elementology as a new scientific discipline. J RadioanalNucl Chem 2006;269:303-9.

[41] Hunter P. A toxic brew we cannot live without. Micronutrients give insights into the interplay between geochemistry and evolutionary biology. EMBO Rep 2008;9(1):15-8.

[42] López-Alonso M. Trace Minerals and Livestock: Not Too Much Not Too Little. International Scholarly Research Notices2012: Article ID 704825

[43] Thompson LA, Darwish WS. Environmental chemical contaminants in food: Review of a global problem. J Toxicol 2019: 2345283

[44] Liebscher K., Smith H. Essential and nonessential trace elements. A method of determining whether an element is essential or nonessential in human tissue. Arch Environ Health 1968;17:882-91.

[45] Zaichick S, Zaichick V. The effect of age on Ag, $\mathrm{Co}, \mathrm{Cr}, \mathrm{Fe}, \mathrm{Hg}, \mathrm{Sb}, \mathrm{Sc}, \mathrm{Se}$, and $\mathrm{Zn}$ contents in intact human prostate investigated by neutron activation analysis. ApplRadiatIsot2011;69:82733.

[46] Zaichick S, Zaichick V, Nosenko S, Moskvina I. Mass fractions of 52 trace elements and zinc trace element content ratios in intact human prostates investigated by inductively coupled plasma mass spectrometry. Biol Trace Elem Res 2012;149:171-83.

[47] Zaichick V, Zaichick S. INAA application in the assessment of chemical element mass fractions in adult and geriatric prostate glands. ApplRadiatIsot2014;90:62-73.

[48] Zaichick V, Zaichick S. Use of INAA and ICP-MS for the assessment of trace element mass fractions in adult and geriatric prostate. J RadioanalNucl Chem 2014;301:383-97. 
[49] Zaichick V, Zaichick. Differences between chemical element contents in hyperplastic and nonhyperplastic prostate glands investigated by neutron activation analysis Biol Trace Elem Res 2015;164:25-35.

[50] Zaichick V. The variation with age of 67 macroand microelement contents in nonhyperplastic prostate glands of adult and elderly males investigated by nuclear analytical and related methods. Biol Trace Elem Res 2015;168:44-60.

[51] Zaichick V, Zaichick S.Variations in concentration and histological distribution of $\mathrm{Ag}, \mathrm{Co}, \mathrm{Cr}, \mathrm{Fe}, \mathrm{Hg}$, $\mathrm{Rb}, \mathrm{Sb}, \mathrm{Sc}, \mathrm{Se}$, and $\mathrm{Zn}$ in nonhyperplastic prostate gland throughout adulthood. J J Cell Mol Bio. 2016;2(1):011.

[52] Zaichick V, Zaichick S. Age-related changes in concentration and histological distribution of 54 trace elements in nonhyperplastic prostate of adults. Int Arch UrolComplic 2016;2(2):019.

[53] Zaichick S, Zaichick V.Prostatic tissue levels of 43 trace elements in patients with BPH.Br J Med \& Med Res 2016;15(2):1-12.

[54] Zaichick V, Zaichick S. Prostatic tissue levels of 43 trace elements in patients with prostate adenocarcinoma. Cancer and Clinical Oncology 2016);5(1):79-94.

[55] Zaichick V, Zaichick S. Chemical Element Contents in Normal and Benign Hyperplastic Prostate. Ann Mens Health Wellness 2017;1(2):1006.

[56] Zaichick V. Differences between 66 chemical element contents in normal and cancerous prostate. J Anal Oncol2017;6:37-56.

[57] Zaichick V, Zaichick S. Comparison of 66 chemical element contents in normal and benign hyperplastic prostate. Asian J Urol 2019;6:27589.

[58] Isaacs J.T. Prostatic structure and function in relation to the etiology of prostatic cancer. The Prostate 1983;4(4):351-66.

[59] Leissner KM,Fielkegard B, Tisell LE. Concentration and content of zinc in human prostate. Invest Urol 1980;18:32-5.
[60] Woodard HQ, White DR. The composition of body tissues. Br J Radiol 1986;59:1209-1218.

[61] Arnold W.N., Thrasher J.B. Selenium concentration in the prostate. Biol Trace Elem Res 2003;91(3):277-80.

[62] Tipton IH, Cook MJ. Trace elements in human tissue. Part II. Adult subjects from the United States. Health Phys 1963;9:103-45.

[63] Schroeder HA, Nason AP, Tipton IH, Balassa JJ. Essential trace metals in man: Zinc. Relation to environmental cadmium. J Chron Dis 1967;20:179-210.

[64] Saltzman BE, Gross SB, Yeager DW, Meiners BG, Gartside PS. Total body burdens and tissue concentrations of lead, cadmium, copper, zinc, and ash in 55 human cadavers. Environ Res 1990;52:126-45.

[65] Zaichick V. Sampling, sample storage and preparation of biomaterials for INAA in clinical medicine, occupational and environmental health. In: Harmonization of Health-Related Environmental Measurements Using Nuclear and Isotopic Techniques. Vienna: IAEA;1997. p. 123-133.

[66] Zaichick V. Losses of chemical elements in biological samples under the dry ashing process. Trace Elements in Medicine (Moscow) 2004;5(3):17-22.

[67] Kim S-A, Kwon YM, Kim S, Joung H. Assessment of dietary mercury intake and blood mercury levels in the Korean population: Results from the Korean National Environmental Health Survey 2012-2014. Int J Environ Res Public Health 2016;13(9):877.

[68] Wang G, Gong Y,Zhu Y=X, Miao A-J, Yang L-Y, Zhong $\mathrm{H}$. Assessing the risk of $\mathrm{Hg}$ exposure associated with rice consumption in a typical city (Suzhou) in Eastern China. Int J Environ Res Public Health 2017;14(5):525.

[69] Bernhoft RA. Mercury toxicity and treatment: A review of the literature. Journal of Environmental and Public Health 2012: Article ID 460508. 
A Systematic Review of the Mercury Content of the Normal Human Prostate Gland

[70] Kuras R, Janasik B, Stanislawska M, KozlowskaL, Wasowicz W. Assessment of Mercury Intake from Fish Meals Based on Intervention Research in the Polish Subpopulation. Biol Trace Elem Res 2017;179:23-31.

[71] Vernadsky VI. Living Matter, Nauka, Moscow, 1978.
[72] Zaichick V, Ermidou-Pollet S, Pollet S. Medical elementology: a new scientific discipline. Trace Elem Electroly 2007;24(2):69-74.

[73] Hylander LD, Meili M. 500 years of mercury production: global annual inventory by region until 2000 and associated emissions. Sci Total Environ 2003;304(1-3):13-27.

Citation: Prof. Dr V. Zaichick. A Systematic Review of the Mercury Content of the Normal Human Prostate Gland. Archives of Urology. 2020; 3(2): 35-45.

Copyright: (C) 2020 Prof. Dr V. Zaichick. This is an open access article distributed under the Creative Commons Attribution License, which permits unrestricted use, distribution, and reproduction in any medium, provided the original work is properly cited. 